\title{
STRATEGI PEMANFAATAN KOTORAN SAPI
}

\section{STRATEGY OF UTILIZATION COW FECES}

\author{
Hermain Teguh Prayitno \\ Kantor Penelitian dan Pengembangan Kabupaten Pati \\ Email : hermain_prayitno@yahoo.com
}

Naskah Masuk: 20 Mei $2014 \quad$ Naskah Revisi: 28 Mei $2014 \quad$ Naskah Diterima: 6 Juni 2014

\begin{abstract}
Cow feces abundant in the pati district. In the theory, anaerobic organic matter change into inorganic produce energy. Meanwhile, scarcity and rising prices of LPG and chemical fertilizers are common, due to the disparity subsidized and non-subsidized price. Purpose of the study is to know the strategy of utilization cow faces, with descriptive quantitative method and SWOT analysis. Internal factors and external factors assessed by the results of 2.38 and 2.92, the positioning strategy of growth through horizontal integration and stability that is intensified and innovation process of making biogas, liquid manure, solid manure becomes easier, cheaper and can be emulated to provide own needs, and towards the avaibility of farmers to face post-subsidy removal.
\end{abstract}

Keywords : cow feces, biogas, liquid and solid fertilizer

\begin{abstract}
ABSTRAK
Kotoran sapi berlimpah di kabupaten pati. Dalam teori, perubahan anaerob bahan organik menjadi anorganik menghasilkan energi. Sementara, kelangkaan dan peningkatan harga LPG dan pupuk kimia sering terjadi, akibat adanya disparitas harga subsidi dan non subsidi. Tujuan penelitian ingin mengetahui strategi pemanfaatan kotoran sapi, dengan metode deskriptif kuantitatif dan analisis SWOT. Faktor internal dan faktor eksternal dinilai dengan hasil 2,38 dan 2,92 pada posisi strategi pertumbuhan melalui integrasi horisontal dan stabilitas yaitu menggiatkan dan menginovasi proses pembuatan biogas, pupuk cair, pupuk padat menjadi lebih mudah, murah dan dapat ditiru untuk mencukupi kebutuhan sendiri, dan menuju ketahanan peternak dan petani menghadapi paska pencabutan subsidi.
\end{abstract}

Kata kunci : kotoran sapi, biogas, pupuk cair dan padat 


\section{PENDAHULUAN}

Sebagai bentuk keberpihakan pemerintah terhadap upaya peningkatan kesejahteraan masyarakat, pemerintah memberikan subsidi diantaranya dalam bidang energi, seperti penyediaan LPG 3 $\mathrm{kg}$ dan subsidi pertanian, seperti penyediaan pupuk. Menurut (Munawar, 2013), kebijakan subsidi yang dilakukan pemerintah selalu menimbulkan pendapat pro dan kontra. Ada kalangan yang berpendapat bahwa subsidi itu tidak sehat sehingga berapapun besarnya, subsidi harus dihapuskan dari APBN. Sementara pihak lain berpendapat bahwa subsidi masih diperlukan untuk mengatasi masalah kegagalan pasar. Pelaksanaan subsidi perlu dilakukan perubahan disesuaikan dengan kondisi. Misalkan, pengalihan subsidi secara bertahap dari subsidi harga yang kurang efektif dan tidak tepat sasaran kepada subsidi bahan-bahan kebutuhan pokok bagi masyarakat kurang mampu (targeted subsidy). Pemerintah diharapkan tetap mempertahankan kebijakan subsidi baik subsidi energi maupun subsidi nonenergi karena subsidi ini masih diperlukan terutama oleh golongan yang memiliki daya beli rendah. Kebijakan subsidi nonenergi supaya lebih fokus kepada program subsidi untuk mengurangi beban masyarakat miskin, dan membantu usaha kelompok kecil dan menengah. Misalkan lebih fokus kepada subsidi pupuk atau subsidi benih, dan apabila pemerintah akan menerapkan kebijakan pengurangan subsidi secara bertahap, maka harus dipilih terlebih dahulu skenario yang berdampak paling kecil dan berdasarkan database kependudukan yang akurat.

Kebijakan penyesuaian harga BBM bersubsidi di dalam negeri yang telah dilaksanakan Pemerintah sejak 22 Juni
2013 jelas telah mampu menurunkan beban belanja subsidi. Peningkatan harga BBM bersubsidi yang disertai kebijakan pengelolaan konsumsi BBM diharapkan dapat mendorong penghematan konsumsi BBM dalam negeri dan menghambat pertumbuhan impor migas yang terlalu tinggi. Adapun subsidi non-energi masih diperlukan oleh mereka yang memiliki keterbatasan daya beli. Ketahanan pangan dan stabilisasi harga akan tetap dilanjutkan. Alokasi dana subsidi nonenergi tersebut antara lain akan digunakan untuk kebijakan subsidi pangan untuk meningkatkan produksi dan ketersediaan pasokan (subsidi beras, benih, dan pupuk), serta alokasi dana cadangan untuk melakukan operasi pasar dan penyediaan beras untuk rakyat miskin. Alokasi dana cadangan juga disediakan untuk mengantisipasi tekanan kelangkaan bahan pangan di pasar domestik. Adapun permasalahan utama subsidi non-energi adalah subsidi yang diberikan pemerintah cenderung masih kurang daripada yang dibutuhkan masyarakat. Namun, hal ini dapat dipahami karena alasan keterbatasan kemampuan anggaran yang dimiliki oleh pemerintah.

Permasalahan yang banyak terjadi berkaitan dengan subsidi LPG $3 \mathrm{~kg}$ dan subdisi pupuk adalah kelangkaan ketersediaan barang di masyarakat. Kondisi ini terjadi di Kabupaten Pati beberapa waktu terakhir sebagaimana dilaporkan oleh Pas FM tanggal 2 Mei 2014 bahwa telah terjadi demo masyarakat karena kelangkaan dan kenaikan harga barang-barang subsidi akibat pengurangan kuota pupuk serta penimbunan LPG $3 \mathrm{~kg}$.

Alternatif yang sering dikemukakan untuk mengatasi kedua masalah tersebut adalah pengembangan energi alternatif terbarukan dan pengalihan penggunaan pupuk kimia menjadi pupuk organik. Kedua upaya tersebut dapat disinergikan melalui pemanfaatan kotoran hewan peternakan, yaitu menjadi biogas dan 
pupuk organik. Pada umumnya hewan ternak yang dapat dikembangkan untuk kedua tujuan tersebut adalah sapi karena kotoran sapi telah mengandung bakteri penghasil gas metana yang terdapat dalam perut ruminansia. Bakteri tersebut membantu dalam proses fermentasi sehingga mempercepat proses pembentukan biogas (Sufiandi dalam Mayasari dkk, 2010)

Wahyudi (2013), menyatakan pemanfaatan kotoran sapi menjadi biogas dan pupuk organik memiliki nilai strategi karena dapat mendukung pencapaian empat tujuan MDG's, yaitu menanggulangi kemiskinan dan kelaparan (MDG-1), Mendorong Persamaan Gender dan Pemberdayaan Perempuan (MDG-2), Memerangi HIV / AIDS, malaria, dan penyakit lainnya (MDG-3), dan Memastikan Kelestarian Lingkungan Hidup (MDG-7). Kabupaten Pati sebagai wilayah dengan usaha pertanian dan peternakan yang tersebar hampir di seluruh kecamatan sangat potensial untuk pengolahan kotoran sapi. Berdasarkan data dari BPS Kab. Pati (2013), rata-rata kepemilikan sapi adalah 1-2 sapi /peternak. Oleh karenanya pengolahan kotoran sapi yang dapat dikembangkan adalah dalam bentuk skala kecil.

Kelangkaan LPG $3 \mathrm{~kg}$ dan pupuk sering terjadi dan kita rasakan, karena barang tersebut adalah salah satu dari beberapa barang yang disubsidi pemerintah. Kepemilikan seseorang terhadap beberapa barang subsidi jika ditahan beberapa waktu, baik sekala kecil (rumah tangga) maupun usaha akan berdampak adanya kelangkaan barang di pasaran. Diasumsikan jika satu rumah tangga mempunyai 2 tabung LPG $3 \mathrm{~kg}$ yang salah satunya dipakai maka tabung LPG lainnya akan disimpan sebagai cadangan dengan tujuan agar tidak mengganggu aktivitas memasak tatkala tabung pertama habis. Kesengajaan ataupun ketidaksengajaan kepemilikan barang tersebut telah meningkatkan cadangan dua kali lipat kebutuhan riil. Apalagi hal tersebut dilakukan juga oleh masyarakat ekonomi menengah ke atas dan atau oleh usaha, baik industri kecil menengah dan besar, juga oleh usaha perdagangan. Maka kelangkaan semua barang subsidi dipastikan akan sering terjadi.

Penelitian energi dan pupuk alternatif ini telah banyak dilakukan, dicoba dan diaplikasikan oleh pemerintah yaitu tahun 2010 hingga 2014 pada kegiatan pengembangan pupuk organik dan biogas, (Permentan, 2010). Namun masih belum memberikan minat ketertarikan masyarakat untuk mencoba dan mengaplikasikannya. Permasalahan ini harus segera dicari solusi strateginya, dikarenakan penipisan sumber daya alam tentang minyak bumi sebagai bahan dasar pembuatan energi dan pupuk menjadi habis. Berdasarkan paparan tersebut, tujuan dari penelitian ini adalah merumuskan strategi pemanfaatan kotoran sapi melalui ekplorasi faktor internal dan faktor eksternal masyarakat peternak di Kabupaten Pati.

\section{TINJAUAN PUSTAKA}

Menurut (Wahyuni dkk, 2008), pupuk adalah bahan yang ditambahkan ke dalam tanah untuk menyediakan unsurunsur esensial bagi pertumbuhan tanaman. Penggolongan pupuk umumnya didasarkan pada sumber bahan yang digunakan, cara aplikasi, bentuk dan kandungan unsur hara. Berdasarkan sumber bahan yang digunakan, pupuk dapat dibedakan menjadi pupuk organik dan pupuk anorganik.

Pupuk organik adalah pupuk yang bahan dasarnya terdiri dari bahan organik yang diambil dari alam dengan jumlah dan jenis unsur hara yang terkandung secara alami, sedang pupuk anorganik adalah 
pupuk yang berasal dari bahan non organik yang umumnya diproduksi melalui proses sintetis yang menghasilkan senyawa kimia yang mudah diserap oleh tanaman. Dari bentuk pupuk organik dapat dikelompokkan menjadi 2 (dua) yakni pupuk organik cair dan pupuk organik padat. Pupuk cair adalah larutan yang mudah larut, berisi satu atau lebih pembawa unsur yang dibutuhkan tanaman. Pupuk padat adalah pupuk organik yang bentuknya padat, remah, tidak berbau, jika dilarutkan ke dalam air tidak mudah larut. Pupuk organik termasuk pupuk majemuk lengkap karena kandungan unsur haranya lebih dari satu unsur dan mengandung unsur mikro. Pupuk organik padat adalah pupuk yang sebagian besar atau seluruhnya terdiri atas bahan organik yang berasal dari sisa tanaman, kotoran hewan dan kotoran manusia yang berbentuk padat.

Keunggulan pupuk organik dibandingkan pupuk anorganik karena mengandung unsur hara yang lengkap, baik hara makro maupun unsur hara mikro; mengandung asam-asam organik antara lain asam humic, asam fulfic, hormon dan enzim; mengandung makro dan mikro organisme tanah; memperbaiki dan menjaga struktur tanah; sebagai penyangga $\mathrm{pH}$; menjaga kelembaban tanah; tidak ada batasan aplikasi atau kebanyakan dosis dan tidak merusak tanah. Kekurangan pupuk organik adalah kandungan atau kualitas hara yang relatif kecil sehingga membutuhkan volume pupuk yang banyak; jumlah pupuk yang banyak sehingga akan menambah biaya pemakain dan transportasinya; reaksi pupuk yang berjalan lambat.

Pupuk organik banyak diperoleh dari bahan-bahan organik yang telah mengalami dekomposisi oleh mikroorganime pengurai. Limbah (sludge) yang diperoleh dari instalasi biogas juga bisa digunakan sebagai pupuk organik, baik pupuk organik padat maupun pupuk organik cair. Hal ini sesuai dengan hasil penelitian Wahyudi dan Astuti (2011) yang menyatakan bahwa limbah biogas (slurry) dapat digunakan sebagai pupuk organik. Pemanfaatan sludge sebagai pupuk padat memberikan keuntungan yang hampir sama dengan penggunaan kompos. Di kawasan pertanian sludge dapat langsung dialirkan ke area pertanian sebagai pupuk, yang memiliki kualitas lebih baik dibandingkan dengan kotoran sapi segar. Unsur hara yang ada dalam pupuk organik cair cepat terurai sehingga mudah diserap tanaman. Sludge yang berasal dari biogas sangat baik untuk dijadikan pupuk karena mengandung berbagai mineral yang dibutuhkan oleh tumbuhan seperti Fospor (P), Magnesium (Mg), Kalsium (Ca), Kalium (K), Tembaga (Cu), dan Seng (Zn).

\section{METODE PENELITIAN}

Penelitian menggunakan pendekatan deskriptif kuantitatif. Data yang digunakan adalah data sekunder dan data observasi lapangan, yaitu peninjauan kondisi beberapa bangunan biogas yang telah ada di Kabupaten Pati. Metode analisa data dengan analisis deskriptif dengan formulasi strategi terdiri dari faktor strategi internal dan eksternal (IFAS dan EFAS), Matriks Internal dan eksternal (IE), dan Matriks SWOT.

\section{HASIL DAN PEMBAHASAN}

Upaya pemanfaatan kotoran sapi telah dilakukan orang atau kelompok sejak lama yaitu menjadi pupuk kandang. Akan tetapi dalam perkembangannya, proses pengolahannya dibuat menjadi lebih praktis dan mampu mendapatkan nilai ekonomi yang lebih dibandingkan dengan pupuk kandang.

Secara alami semua kotoran sapi dari feces, kencing, dan sisa kandang mudah menjadi pupuk kandang dengan menempatkan bahan tersebut ke dalam 
lubang tanah dan dibiarkan lama. Tetapi ternyata dalam banyak penelitian diketahui bahwa dalam prosesnya, bahan-bahan tersebut mampu mengeluarkan gas yang dikenal dengan biogas (metana). Pemanfaatan kotoran sapi menjadi biogas, pupuk cair, dan pupuk padat telah banyak diteliti dan dipraktekkan, bahkan telah mampu dibuktikan dengan aplikasi pada tanaman.
Pemanfaatan kotoran sapi menjadi pengganti LPG dan pupuk ternyata belum banyak diminati dan ditiru oleh masyarakat kita, hal ini berdasarkan jawaban masyarakat tentang keberadaan bangunan maupun peralatan dan proses pengolahan kotoran sapi. Faktor-faktor internal dan eksternal analisis pemanfaatan kotoran sapi seperti disajikan pada Tabel 1 dan Tabel 2.

Tabel 1.

Faktor Internal Pemanfaatan Kotoran Sapi

\begin{tabular}{|c|c|c|c|c|}
\hline Faktor-faktor Strategi Internal & Bobot & Rating & Skor & Komentar \\
\hline \multicolumn{5}{|l|}{ S Kekuatan } \\
\hline $\begin{array}{l}\text { Kotoran sapi melimpah (peternak } \\
\text { tersebar merata) }\end{array}$ & 0,15 & 4 & 0,60 & $\begin{array}{l}\text { Peternak ekonomi kecil atau } \\
\text { peternak jasa }\end{array}$ \\
\hline Proses pengolahan simpel sederhana & 0,07 & 4 & 0,28 & $\begin{array}{l}\text { Kotoran dibiarkan menjadi pupuk } \\
\text { kandang }\end{array}$ \\
\hline Peralatan tersedia dan murah & 0,07 & 2 & 0,14 & Tergantung Besar kecil jauh dekat \\
\hline $\begin{array}{l}\text { Kotoran sapi mudah berubah } \\
\text { menjadi biogas }\end{array}$ & 0,07 & 2 & 0,14 & $\begin{array}{l}\text { Kualitas biogas tergantung jenis } \\
\text { sapi }\end{array}$ \\
\hline $\begin{array}{l}\text { Kotoran sapi mudah berubah } \\
\text { menjadi pupuk cair }\end{array}$ & 0,07 & 3 & 0,21 & $\begin{array}{l}\text { Kualitas pupuk cair tergantung } \\
\text { jenis sapi dan mineral tambahan }\end{array}$ \\
\hline $\begin{array}{l}\text { Kotoran sapi mudah berubah } \\
\text { menjadi pupuk padat }\end{array}$ & 0,07 & 4 & 0,28 & $\begin{array}{l}\text { Kotoran dibiarkan menjadi pupuk } \\
\text { kandang }\end{array}$ \\
\hline \multicolumn{5}{|l|}{ W Kelemahan } \\
\hline Bangunan biogas dari semen mahal & 0,085 & 4 & 0,34 & $\begin{array}{l}\text { Bangunan anti bocor gas } \\
\text { membutuhkan semen yang banyak }\end{array}$ \\
\hline $\begin{array}{l}\text { Bangunan biogas dari semen } \\
\text { membutuhkan tempat luas }\end{array}$ & 0,085 & 4 & 0,34 & $\begin{array}{l}\text { Reaktor bio, pengumpul dan } \\
\text { penyaring harus satu kesatuan }\end{array}$ \\
\hline $\begin{array}{l}\text { Percontohan biogas pemerintah } \\
\text { belum dicontoh }\end{array}$ & 0,08 & 4 & 0,32 & $\begin{array}{l}\text { Belum ada pengadaan biogas } \\
\text { bangunan mandiri }\end{array}$ \\
\hline $\begin{array}{l}\text { Percontohan dan alat dari swasta } \\
\text { belum di minati }\end{array}$ & 0,08 & 4 & 0,32 & $\begin{array}{l}\text { Masih banyak kendala dan mudah } \\
\text { rusak }\end{array}$ \\
\hline $\begin{array}{l}\text { Pupuk kompos mahal ( produksi dan } \\
\text { transportasi ) }\end{array}$ & 0,08 & 2 & 0,16 & $\begin{array}{l}\text { Volumenya yang besar dan } \\
\text { kualitas rendah }\end{array}$ \\
\hline \multirow[t]{2}{*}{$\begin{array}{l}\text { Daya serap tanaman pada pupuk } \\
\text { kompos lambat }\end{array}$} & 0,09 & 3 & 0,27 & Produk alami bukan instan \\
\hline & 1 & & 2,38 & \\
\hline
\end{tabular}

Sumber: Pengolahan Data, (2014) 
Tabel 2.

Faktor Eksternal Pemanfaatan Kotoran Sapi

\begin{tabular}{|c|c|c|c|c|}
\hline Faktor-faktor Strategi Eksternal & Bobot & Rating & Skor & komentar \\
\hline \multicolumn{5}{|l|}{ Peluang } \\
\hline $\begin{array}{l}\text { LPG sebagai energi tak terbarukan } \\
\text { semakin mahal dan habis }\end{array}$ & 0,067 & 2 & 0,13 & Subsidi lambat laun di kurangi \\
\hline $\begin{array}{l}\text { Biogas pengganti LPG yang sudah } \\
\text { dikenal dan dibutuhkan }\end{array}$ & 0,15 & 3 & 0,45 & $\begin{array}{l}\text { Mudah berubah dari LPG ke } \\
\text { biogas }\end{array}$ \\
\hline $\begin{array}{l}\text { Semua jenis tanaman tetap } \\
\text { membutuhkan pupuk }\end{array}$ & 0,15 & 2 & 0,3 & $\begin{array}{l}\text { Pupuk kimia akan menjadi } \\
\text { mahal merusak tanah mudah } \\
\text { diganti kompos }\end{array}$ \\
\hline $\begin{array}{l}\text { Pemerintah jangka panjang } \\
\text { mengurangi subsidi energi dan pupuk }\end{array}$ & 0,1 & 2 & 0,2 & $\begin{array}{l}\text { Menaikkan minat biogas dan } \\
\text { kompos }\end{array}$ \\
\hline $\begin{array}{l}\text { Pemerintah selalu mendukung energi } \\
\text { alternatif terbarukan }\end{array}$ & 0,1 & 4 & 0,4 & $\begin{array}{l}\text { Dukungan pendanaan dan } \\
\text { penelitian }\end{array}$ \\
\hline \multicolumn{5}{|l|}{ Ancaman } \\
\hline $\begin{array}{l}\text { Masyarakat terbiasa LPG praktis harga } \\
\text { Subsidi }\end{array}$ & 0,067 & 3,5 & 0,23 & $\begin{array}{l}\text { Jarak dan risiko kebakaran } \\
\text { Mengurangi minat LPG }\end{array}$ \\
\hline $\begin{array}{l}\text { Masyarakat terbiasa pupuk kimia } \\
\text { praktis harga subsidi }\end{array}$ & 0,066 & 3,5 & 0,23 & $\begin{array}{l}\text { Sebagian kecil masih } \\
\text { menggunakan pupuk kandang }\end{array}$ \\
\hline $\begin{array}{l}\text { Konsumen suka pupuk kimia reaksi } \\
\text { cepat }\end{array}$ & 0,075 & 3 & 0,23 & $\begin{array}{l}\text { Tanaman mudah diserang hama } \\
\text { dan pupuk kandang berlimpah }\end{array}$ \\
\hline $\begin{array}{l}\text { Pupuk saprodi tersedia dekat dengan } \\
\text { petani }\end{array}$ & 0,15 & 4 & 0,6 & Meringankan biaya transportasi \\
\hline \multirow[t]{2}{*}{$\begin{array}{l}\text { Kotoran sapi peternak kecil diambil } \\
\text { oleh pengusaha kompos }\end{array}$} & 0,075 & 2 & 0,15 & $\begin{array}{l}\text { Tidak mempunyai tempat } \\
\text { mengolah dan praktis dijual }\end{array}$ \\
\hline & 1 & & 2,92 & \\
\hline
\end{tabular}

Sumber: Pengolahan Data, (2014)

Nilai faktor internal yaitu 2,38 pada posisi pertumbuhan melalui integrasi horisontal dan faktor eksternal nilainya 2,92 pada posisi stabilitas, dan strategi masing-masing serta keduanya disampaikan sebagai berikut:

Strategi pertumbuhan integrasi horisontal dengan cara memperluas kegiatan lini produk atau membangun di tempat lain dengan tujuan meningkatkan jenis produk dan jasa. Dalam hal ini arah strategi dititik beratkan pada peternak kecil tersebar sebagai produsen dan petani sekitar sebagai konsumen. Strategi stabilitas dengan cara penggambaran saat ini masih berlanjut untuk jangka pendek dan akan berubah sesuai keadaan pada jangka panjang. Strategi pertumbuhan integrasi horisontal dan stabilitas dengan cara strategi jangka pendek mempersiapkan untuk memperbanyak produsen dan mendekatkan dengan konsumen untuk kestabilan jangka panjang. 
Tabel 3.

Diagram SWOT Matriks Strategi Pemanfaatan Kotoran Sapi

\begin{tabular}{|c|c|c|}
\hline \multirow{14}{*}{ EFAS } & S Kekuatan & W Kelemahan \\
\hline & Kotoran & \multirow{5}{*}{$\begin{array}{l}\text { 1. Bangunan Biogas Dari } \\
\text { Semen Mahal } \\
\text { 2. Bangunan Biogas Dari } \\
\text { Semen Membutuhkan } \\
\text { Tempat }\end{array}$} \\
\hline & Melimpah & \\
\hline & Tersebar Merata) & \\
\hline & 2. Proses Pengolahan & \\
\hline & Simpel Sederhana & \\
\hline & 3. Peralatan & \multirow{8}{*}{$\begin{array}{l}\text { 3. Percontohan Biogas } \\
\text { Pemerintah Belum Dicontoh } \\
\text { 4. Percontohan Dan Alat Dari } \\
\text { Swasta Belum Di Minati } \\
\text { 5. Pupuk Kompos Mahal } \\
\text { (Produksi Dan Transportasi) } \\
\text { 6. Daya Serap Tanaman Pada } \\
\text { Pupuk Kompos Lambat }\end{array}$} \\
\hline & Dan Murah & \\
\hline & 4. Kotoran Sapi Mudah & \\
\hline & Berubah Menjadi Biogas & \\
\hline & 5. Kotoran Sapi Mudah & \\
\hline & Berubah Menjadi Pupuk Cair & \\
\hline & Kotoran Sapi Mudah & \\
\hline & $\begin{array}{l}\text { Berubah Menjadi Pupuk } \\
\text { Padat }\end{array}$ & \\
\hline \multirow{2}{*}{$\begin{array}{c}\text { O Peluang } \\
\text { 1. Biogas Energi Terbarukan }\end{array}$} & SO pemanfaatan peluang & \multirow{3}{*}{$\begin{array}{c}\text { WO meminimalkan } \\
\text { kelemahan memanfaatkan } \\
\text { peluang }\end{array}$} \\
\hline & 1. Upaya Memproduksi Ketiga & \\
\hline \multirow{2}{*}{$\begin{array}{l}\text { 2. Biogas Dan LPG Telah } \\
\text { Dikenal Masy }\end{array}$} & Peluang Yaitu Biogas, & \\
\hline & Pupuk Cair Dan Padat & \multirow{12}{*}{$\begin{array}{l}\text { 1. Inovasi Kesempurnaan } \\
\text { Proses, Peralatan Berbahan } \\
\text { Murah, Dan Berbentuk } \\
\text { Kecil } \\
\text { 2. Meminta Pemerintah Dan } \\
\text { Atau Swasta Percontohan } \\
\text { Produksi Biogas, Pupuk } \\
\text { Cair Dan Padat, Yang } \\
\text { Mudah Dan Mampu } \\
\text { Dicontoh }\end{array}$} \\
\hline 3. Petani Butuh Pupuk & 2. Jangka Pendek Persiapan & \\
\hline $\begin{array}{l}\text { 4. Pengurangan } \\
\text { Penghentian Subsidi }\end{array}$ & $\begin{array}{lrr}\text { Dan } & \text { Ujicoba } & \text { Produksi } \\
\text { Ketiga } & \text { Peluang } & \text { Untuk }\end{array}$ & \\
\hline 5. Dukungan Pemerintah & Kemantapan Usaha Jangka & \\
\hline Tentang Energi Dan Pupuk & Panjang & \\
\hline Alternatif & 3. Kordinasi & \\
\hline \multirow{6}{*}{$\begin{array}{l}\text { 6. Kelangkaan } \\
\text { Pupuk Kimia }\end{array}$} & Dan Swasta & \\
\hline & Bimbingan Dan Bantuan & \\
\hline & 4. Menawarkan Penggunaan & \\
\hline & Biogas Dan Pupuk Organik & \\
\hline & Pada Tetangga Pada Saat & \\
\hline & Kelangkaan Bahan Tersebut & \\
\hline$T$ ancaman & menghindari ancaman & \multirow{2}{*}{$\begin{array}{c}\text { WT meminimalkan } \\
\text { kelemahan untuk } \\
\text { menghindari ancaman }\end{array}$} \\
\hline $\begin{array}{l}\text { 1. LPG Jangka Pendek Tetap } \\
\text { Diminati }\end{array}$ & $\begin{array}{r}\text { 1. Memproduksi } \\
\text { Menggunakan }\end{array}$ & \\
\hline \multirow{2}{*}{$\begin{array}{l}\text { 2. Pupuk Kimia Jan } \\
\text { Pendek Tetap Diminati }\end{array}$} & Energi Dan Pupuk Serta & \multirow{3}{*}{$\begin{array}{l}\text { 1. Usul Pada Pemerintah } \\
\text { Untuk Peralihan Subsidi } \\
\text { Dari LPG Ke Biogas Dan }\end{array}$} \\
\hline & Meninggalkan & \\
\hline \multirow{2}{*}{$\begin{array}{l}\text { 3. Kompos Impor Dan } \\
\text { Pabrikan }\end{array}$} & Pupuk Kimia & \\
\hline & 2. Jangka Pendek & $\begin{array}{l}\text { Dari LPG Ke Biogas Dan } \\
\text { Dari Pupuk Kimia Ke Pupuk }\end{array}$ \\
\hline \multirow{2}{*}{$\begin{array}{l}\text { 4. Pedagang LPG Dan Pupuk } \\
\text { Kimia Dekat Masy. }\end{array}$} & Produksi & \multirow{4}{*}{ 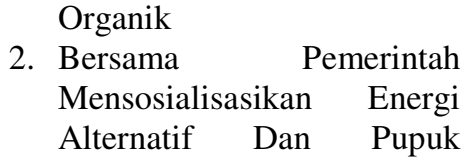 } \\
\hline & Peluang & \\
\hline \multirow{3}{*}{$\begin{array}{l}\text { 5. Kotoran Sapi P } \\
\text { Kecil Diambil } \\
\text { Pengusaha Kompos }\end{array}$} & Kemantapan Usaha Jangka & \\
\hline & Panjang Dan Usul Penolakan & \\
\hline & $\begin{array}{l}\text { Impor Pupuk Kompos } \\
\text { Granul. }\end{array}$ & Organik \\
\hline
\end{tabular}

Sumber: Pengolahan Data, (2014) 
Strategi pertumbuhan melalui integrasi horisontal khusus kekuatan menghadapi peluang yaitu memperbanyak produksi dengan cara mengajak peternak kecil yang tersebar di wilayah Kabupaten Pati, dan memperbanyak jenis produksi yaitu biogas, pupuk cair dan padat. Strategi untuk menghidari ancaman dengan menggunakan sendiri ketiga produk tersebut dalam jangka pendek yaitu ketika masih adanya disparitas harga serta menawarkan produk tersebut kepada konsumen (tetangga) ketika terjadi peningkatan harga di pasaran.

Strategi pertumbuhan melalui integrasi horisontal khusus dengan meminimalkan kelemahan untuk memanfaatkan peluang dengan cara koordinasi bersama pemerintah dan swasta untuk selalu menginovasi kesempurnaan proses, peralatan berbahan murah dan berbentuk kecil sehingga dapat disosialisasikan atau dicontoh oleh peternak lainnya. Strategi meminimalkan kelemahan untuk menghindari ancaman yaitu mengusulkan kepada pemerintah tentang perubahan subsidi LPG dan pupuk menjadi subsidi atau insentif terhadap pengguna biogas dan pupuk organik.

Strategi stabilitas adalah kondisi yang masih sama yaitu hanya pada peternak saja yang dapat menggunakan energi dan pupuk alternatif, untuk konsumen non peternak dalam jangka pendek masih nyaman menggunakan barang subsidi.

\section{KESIMPULAN DAN SARAN}

\section{Kesimpulan}

Memperbanyak produksi biogas, pupuk cair dan pupuk padat dengan cara mengajak peran serta peternak kecil yang letaknya tersebar di wilayah Kabupaten Pati, serta menggunakan sendiri produk tersebut dan menawarkannya kepada petani terdekat untuk menggunakan pupuk organik sebagai pengganti pupuk kimia.
Pemerintah, swasta dan masyarakat bersama-sama untuk selalu mencari inovasi kesempurnaan proses, peralatan berbahan murah dan berbentuk kecil sehingga dapat disosialisasikan dan mudah dicontoh peternak lainnya.

Dukungan pemerintah berbentuk bimbingan dan dana pengadaan peralatan serta dukungan pemberian insentif terhadap penggunan biogas dan pupuk organik.

\section{SARAN}

Pemerintah dan swasta harus selalu mencari teknologi pemanfaatan kotoran sapi yang sederhana, praktis, dan mudah ditiru untuk menunjang kemampuan peternak kecil guna peningkatan ekonomi melalui kemampuan memproduksi biogas, pupuk cair dan padat. Pemerintah daerah harus memberikan dukungan dalam bentuk arahan teknologi dan insentif bagi peternak kecil sebagai produsen dan petani sebagai konsumen produk biogas dan pupuk organik.

\section{DAFTAR PUSTAKA}

Anonimus. 2013. Kekurangan dan Keunggulan Pupuk Organik dan Anorganik. http://asepjb.blogspot.com/.

Diakses tanggal 6 Maret 2014.

Badan Pusat Statistik Kabupaten Pati. 2013. Pati Dalam Angka Tahun 2012. Pati.

Mayasari, H. D. dkk. 2010. Pembuatan Biodigester dengan Ujicoba Kotoran Sapi Sebagai Bahan Baku. Tugas Akhir. Jurusan Teknik Kimia. Fakultas Teknik. Surakarta : Universitas Sebelas Maret.

Munawar, D. 2013. Memahami Pengertian dan Kebijakan Subsidi dalam APBN, Widyaiswara Utama BDK 
Cimahi.

http://www.bppk.depkeu.go.id/bdk/ cimahil

attachments/299_Memahami\%20S ubsidi.pdf. Diakses tanggal 6 Maret 2014.

Pas FM Pati. Demo Masyarakat Pati Akibat Kelangkaan Harga Akibat Pengurangan Kuota Pupuk serta Penimbunan LPG $3 \mathrm{~kg}$. Tanggal 2 Mei 2014.

Peraturan Menteri Pertanian Nomor 19/Permentan/Ot.140/2/2010 tentang Pedoman Umum Program Swasembada Daging Sapi.

Wahyudi, J. 2013. Strategi Pengembangan BiogasPada Peternakan Sapi Perah. Jurnal Litbang, Vol IX (2): 121-127.
Wahyuni, S. dan J. Musanif. 2008. Pembuatan Pupuk Organik Cair dan Pupuk Organik Padat dari Keluaran Digester Biogas. http://pphp.deptan.go.id/xplore/ files/PENGOLAHANHASIL/BIPupukCairDigester.pdf. Diakses tanggal 6 maret 2014.

\section{BIODATA PENULIS}

Hermain Teguh Prayitno, lahir 11 April 1970 di kota Rembang Jawa Tengah. Magister Ilmu Lingkungan dari Universitas Diponegoro (UNDIP) Semarang tahun 2008. Saat ini bekerja sebagai peneliti pertama di Kantor Penelitian dan Pengembangan Kabupaten Pati. 